\title{
Prevention of Hepatitis B
}

\author{
Mei-Hwei Chang ${ }^{1,2}$ and Ding-Shinn Chen ${ }^{2,3,4}$ \\ ${ }^{1}$ Department of Pediatrics, National Taiwan University Hospital, Taipei 10016, Taiwan \\ ${ }^{2}$ Hepatitis Research Center, National Taiwan University Hospital, Taipei 10016, Taiwan \\ ${ }^{3}$ Internal Medicine, National Taiwan University Hospital, Taipei 10016, Taiwan \\ ${ }^{4}$ Genomics Research Center, Academia Sinica, Nankang 11529, Taiwan \\ Correspondence: chends@ntu.edu.tw
}

Hepatitis B virus (HBV) causes life-threatening liver disease. It is transmitted through a horizontal route or a mother-to-infant route, and the latter is the major route in endemic areas. Prevention of HBV infection by immunization is the best way to eliminate HBV-related diseases. The HBV vaccine is the first human vaccine using a viral antigen from infected persons, which is safe and effective. Either passive immunization by hepatitis B immunoglobulin (HBIG) or active immunization by HBV vaccine is effective, and a combination of both yields the best efficacy in preventing HBV infection. The impact of universal HBV immunization is huge, with $90 \%-95 \%$ effectiveness in preventing chronic HBV infection. It is the first cancer preventive vaccine with a protective efficacy against hepatocellular carcinoma (HCC) of $\sim 70 \%$. Nevertheless, further effort is still needed to avoid vaccine failure and to increase the global coverage rate.

$\mathrm{H}$ epatitis B virus (HBV) infection can cause acute, fulminant, or chronic hepatitis, liver cirrhosis, and hepatocellular carcinoma (HCC). It is a potentially life-threatening infection, and is a major global health problem. Around 600,000 people die every year because of the acute or chronic consequences of the infection (www.who.int/mediacentre/factsheets/fs204/ en). Once the infection becomes chronic, it is extremely refractory and is difficult to cure, despite recent developments of treatment measures (Chen 2011). Ultimately, around onethird of the chronically infected patients will eventually develop cirrhosis and HCC. HCC is one of the most common causes of cancer death worldwide because of a poor prognosis and a high recurrence rate after curative therapy. Besides liver disease, HBV infection also causes extrahepatic diseases, such as $\mathrm{HBV}$-associated membranous nephropathy (HBVMN). Children with HBVMN are primarily infected via horizontal transmission. (Hsu et al. 1983; Kappus and Sterling 2013).

For hepatitis B, prevention is more effective than therapy. Despite the progress of antiviral therapy against HBV to suppress viral replication and to reduce complications in those with chronic hepatitis $\mathrm{B}$, a cure for infection is still not possible. Hence, prevention of HBV infection by immunization is the best way to eliminate HBV-related diseases (Chen 2009). The development of an $\mathrm{HBV}$ vaccine using $\mathrm{HBsAg}$

Editors: Christoph Seeger and Stephen Locarnin

Additional Perspectives on Hepatitis B and Delta Viruses available at www.perspectivesinmedicine.org

Copyright (C) 2015 Cold Spring Harbor Laboratory Press; all rights reserved; doi: 10.1101/cshperspect.a021493

Cite this article as Cold Spring Harb Perspect Med 2015;5:a021493 
M.-H. Chang and D.-S. Chen

protein from HBV carriers as the immunogen to induce anti-HBs, the protective antibody against HBV infection, is a successful pioneer in the history of vaccine development. During the past three decades, it is proved to be safe and successful in protecting people from HBV infection and the related diseases worldwide.

Nevertheless, there are problems that hinder the success of HBV prevention globally. Looking back at the history of the development of the $\mathrm{HBV}$ vaccine and immunization strategies and exploring the existing problems might help to eliminate HBV-related diseases.

\section{TRANSMISSION ROUTE OF HBV AND OUTCOMES OF HBV INFECTION AT DIFFERENT AGES}

To prevent HBV infection effectively, it is crucial to understand its route of transmission. HBV infection is transmitted through either a horizontal route or through a mother-to-infant route. Mother-to-infant transmission was called "vertical transmission" in the past, but this term is less frequently used now because it caused confusion with genetic transmission, which does not occur with HBV. In endemic areas, perinatal mother-to-infant transmission is the most important route of transmission; HBV infection is encountered mainly during infancy and early childhood.

Age at infection and source of infection affect the outcome of HBV infection (Beasley 2009). Without immunoprophylaxis, perinatal transmission from highly infectious ( $\mathrm{HBeAg}$ positive) hepatitis B carrier mothers results in chronic infection in $90 \%$ of their infants (Stevens et al. 1975). In contrast, only $5 \%$ of infants of HBeAg-negative HBsAg carrier mothers become chronic carriers and a small fraction may develop acute or fulminant hepatitis B (Shiraki et al. 1980; Chang et al. 1987). Among 2- to 4-yrold toddlers, $\sim 25 \%$ will become chronic carriers (Beasley et al. 1982). In contrast, only $2.7 \%$ of the newly HBV-infected 18- to 19-yr-old university students became chronic carriers (Beasley et al. 1983a). Thus, the younger the age at infection, the higher the HBV carriage rate (Table 1).

\section{PREVENTION AGAINST HBV INFECTION: IMMUNIZATION AND OTHER STRATEGIES}

HBV immunization can be classified into passive and active immunization. Passive immunization using hepatitis B immunoglobulin (HBIG) provides temporary immunity, whereas active immunization by the vaccine yields long-term immunity. Because in endemic areas the major infection route comes from maternal transmission, and the outcome of perinatal transmission results in a very high rate (90\%) of chronic infection, the best timing of initial HBV immunization, therefore, should be within $24 \mathrm{~h}$ after birth, followed by subsequent doses of HBV vaccine during infancy.

Other prevention strategies, such as screening the blood products, proper sterilization of injection needles and syringes, and avoidance of risky behaviors, such as parenteral drug abuse, tattoo, or skin piercing, may preclude HBV horizontal transmission. Education to avoid high-risk behaviors should be advocated in addition to vaccination. In addition to the program for infants, many countries with low prevalence of HBV infection also have HBV vaccination programs for adolescents to prevent

Table 1. Outcome of HBV infection in subjects of different age at transmission with no immunoprophylaxis

\begin{tabular}{lccc}
\hline Age at infection & $\begin{array}{c}\text { Annual infection rate, } \\
(\% \text { anti-HBc } \\
\text { seroconversion } / \mathrm{yr})\end{array}$ & $\begin{array}{c}\text { Chronicity rate } \\
\text { among infected } \\
\left(\% \mathrm{HBsAg}^{+}>6 \mathrm{mo}\right)\end{array}$ & \multicolumn{1}{c}{ References } \\
\hline Infant & $>95 \%$ & $>90 \%$ & Stevens et al. 1975 \\
$\quad$ Mother $\mathrm{HBsAg}^{+}, \mathrm{HBeAg}^{+}$ & $5-10 \%$ & $<5 \%$ & \\
$\quad$ Mother $\mathrm{HBsAg}^{+}, \mathrm{HBeAg}^{-}$ & $5.0 \%$ & $23 \%$ & Beasley et al. 1982 \\
Toddler & $1.5 \%$ & $2.7 \%$ & Beasley et al. 1983a \\
Young adult & & &
\end{tabular}


exposure to HBV by sexual contacts or other risk behaviors.

\section{HEPATITIS B VACCINE DEVELOPMENT}

In 1965, Baruch S. Blumberg reported a "new" antigen, the Australia antigen, in sera of patients with leukemia. He later discovered that the antigen is closely associated with a causal agent of viral hepatitis (Blumberg et al. 1967, 1969). Australia antigen was later found to be the hepatitis B surface antigen (HBsAg). Antibody to HBsAg (anti-HBs) was later shown to be a neutralizing antibody against $\mathrm{HBV}$ infection.

Maurice Hilleman was the pioneer of several important human vaccines, and the HBV vaccine is one of the most important. He hypothesized that, by injecting HBsAg, an antibody to HBsAg could be produced. HBsAg thus became the backbone of the hepatitis B vaccine. A highly purified and inactivated vaccine was made of HBsAg from HBV carrier plasma. Through stringent treatments with pepsin, urea, and formaldehyde, together with rigorous filtration, a safe vaccine was produced that was devoid of infectious agents, including human immunodeficiency virus (HIV). To ensure safety, the vaccine was tested exhaustively by ordinary procedures as well as in chimpanzees and marmosets. It was highly potent and it induced antibodies in guinea pigs, grivet monkeys, and chimpanzees after subcutaneous inoculation. Chimpanzees given three doses of vaccine were protected against challenges with 1000 chimpanzee-infectious doses of HBV given intravenously (Buynak et al. 1976) The first large-scale trials for the plasma vaccine were performed on homosexual men belonging to a high-risk group (Szmuness et al. 1980) The plasma-derived vaccine was approved by the Food and Drug Administration (FDA) in 1981. A similar vaccine was developed in France at almost the same time (Maupas et al. 1981).

Currently, there are two kinds of HBV vaccines, a plasma-derived vaccine, the first-generation vaccine, and the recombinant vaccine, the second-generation vaccine. The recombinant vaccine was produced by expressing the $H B s A g$ gene in the yeast Saccharomyces cerevi- siae (Valenzuela et al. 1982; Hilleman 1987). Both are safe and effective.

\section{ESTABLISHMENT OF THE STRATEGIES OF HBV IMMUNIZATION IN INFANCY BY PILOT CLINICAL TRIALS}

History of the development of the HBV vaccine and immunization program is an excellent model for the development of other preventive and therapeutic vaccines against infectious agentrelated diseases and cancer.

\section{Passive Immunization by HBIG}

Before an HBV vaccine was available, a randomized double-blind, placebo-controlled efficacy trial of passive immunization using HBIG injection for the prevention of mother-to-infant transmission of HBV infection was conducted in Taiwan. HBIG was given within $1 \mathrm{~h}$ after birth to infants of HBeAg-positive HBsAg carrier mothers. The HBsAg carrier rate of the placebo-treated infants was $92 \%$. The HBsAg carrier rate was $26 \%$ among infants who received three doses of HBIG at birth, 3, and 6 mo old, and was $54 \%$ in those who received a single dose at birth. The prevention efficacy was $42 \%$ by one dose of HBIG and $71 \%$ by three doses of HBIG, respectively (Table 2) (Beasley et al. 1983b).

\section{Active Immunization by HBV Vaccine}

The immunogenicity of the hepatitis B virus vaccine was studied in 38 neonates of noncarrier mothers, 23 of whom were healthy and susceptible to HBV infection, and 15 who had anti-HBs passively acquired from their mothers. Initially, each neonate received two $20-\mu \mathrm{g}$ doses of the HBV plasma vaccine by the intramuscular route, with a 1-mo interval between doses. The first dose of vaccine stimulated the production of anti-HBs in $48 \%$ of the neonates within $1 \mathrm{mo}$. Anti-HBs was detectable in the serum of $91 \%$ of vaccine recipients at the age of $3 \mathrm{mo}$, 2 mo after the second dose. By the age of 6 mo, $96 \%$ of vaccinees had detectable anti-HBs. At the age of $7 \mathrm{mo}$, all had developed anti-HBs after a third dose. High levels of anti-HBs were sustained after vaccination in infants who initially 
M.-H. Chang and D.-S. Chen

Table 2. Comparisons of the prevention of HBV infection in infants or immunogenicity of different strategies among different risk groups ${ }^{\text {a }}$

\begin{tabular}{|c|c|c|c|}
\hline & $\begin{array}{l}\text { Infants of } \mathrm{HBsAg}^{+}, \mathrm{HBeAg}^{+} \\
\text {mothers }\end{array}$ & $\begin{array}{l}\text { Infants of } \mathrm{HBsAg}^{+}, \\
\mathrm{HBeAg}^{-} \text {mothers }\end{array}$ & $\begin{array}{l}\text { Immunogenicity in } \\
\text { low-risk infants } \\
\text { (infants or children } \\
\text { of HBsAg- mothers) }\end{array}$ \\
\hline \multicolumn{4}{|l|}{$\begin{array}{l}\text { HBIG only (Beasley et al. } \\
\text { 1983b) }\end{array}$} \\
\hline One dose, $1.0 \mathrm{~mL}$ & $\mathrm{HBsAg}^{+}, 54 \%$, efficacy $45 \%$ & - & - \\
\hline Three doses, $0.5 \mathrm{~mL}$ & $\mathrm{HBsAg}^{+}, 26 \%$, efficacy $75 \%$ & & \\
\hline Placebo & $\mathrm{HBsAg}^{+}, 92 \%$ & & \\
\hline \multirow[t]{4}{*}{ HBV plasma vaccine } & $\begin{array}{l}\text { Vaccine, three doses (RP Beasley } \\
\text { and L-Y Hwang, unpubl.) }\end{array}$ & \multirow{4}{*}{$\begin{array}{l}\text { Vaccine, four doses } \\
\text { (Tsai et al. 1984), } \\
\text { HBsAg }^{+}, 0 \% \\
\text { Placebo, } \mathrm{HBsAg}^{+}, 5.3 \%\end{array}$} & $\begin{array}{l}\text { Anti-HBs (Lee et al. } \\
\text { 1983) }\end{array}$ \\
\hline & $1 \mathrm{wk}, 1,6 \mathrm{mo}, \mathrm{HBsAg}^{+}, 23 \%$ & & After one dose, $48 \%$ \\
\hline & $1,2,6 \mathrm{mo}, \mathrm{HBsAg}^{+}, 38 \%$ & & After two doses, $96 \%$ \\
\hline & Placebo $\mathrm{HBsAg}^{+}, 88 \%$ & & $\begin{array}{l}\text { After three doses, } \\
\quad 100 \%\end{array}$ \\
\hline \multirow[t]{5}{*}{$\begin{array}{l}\text { Combination of HBV } \\
\text { plasma vaccine and } \\
\text { HBIG, } 0.5 \mathrm{~mL} / \text { dose }\end{array}$} & $\begin{array}{l}\text { HBIG birth, } 3 \text { mo + vaccine, } \\
\text { 3, } 4,9 \text { mo, HBsAg } 2.0 \% \\
\text { (Beasley et al. 1983c) }\end{array}$ & $\begin{array}{l}\text { HBIG + vaccine, } 0,1, \\
6 \text { mo, HBsAg }+, \\
<1 \% \text { (Yang et al. 2003) }\end{array}$ & - \\
\hline & $\begin{array}{l}\text { HBIG birth + vaccine } 0,1, \\
6 \text { mo, } \text { HBsAg }^{+}, 6.0 \% \\
\text { (Beasley et al. } 1983 \mathrm{c} \text { ) }\end{array}$ & $\begin{array}{l}\text { Vaccine, } 0,1,6 \mathrm{mo} \\
\mathrm{HBsAg}^{+}<1 \%\end{array}$ & \\
\hline & $\begin{array}{l}\text { HBIG birth + vaccine, } 1,2 \text {, } \\
7 \text { mo, } \mathrm{HBsAg}^{+}, 8.6 \% \\
\text { (Beasley et al. } 1983 \mathrm{c} \text { ) }\end{array}$ & & \\
\hline & $\begin{array}{l}\text { HBIG birth + vaccine, } 0,1,2 \text {, } \\
12 \text { mo, } \mathrm{HBsAg}^{+}, 11 \%(\mathrm{Hsu} \\
\text { et al. 1988) }\end{array}$ & & \\
\hline & $\begin{array}{l}\text { Placebo, } \mathrm{HBsAg}^{+}, 88.1 \% \\
\quad \text { (Beasley et al. 1983c) }\end{array}$ & & \\
\hline \multirow[t]{2}{*}{$\begin{array}{l}\text { Combination of } \mathrm{HBV} \\
\text { recombinant vaccine }+ \\
\text { one dose } \mathrm{HBIG}, 0.5 \mathrm{~mL}\end{array}$} & $\begin{array}{l}\text { HBIG + vaccine } 0,1,6 \text { mo, } \\
\text { HBsAg }^{+}, 3.3 \% \text { (Lee et al. } \\
\text { 1991) }\end{array}$ & $\begin{array}{l}\text { HBIG + vaccine } 0,1, \\
6 \text { mo, HBsAg }{ }^{+}, 0.14 \% \\
(\text { Chen et al. } 2012)\end{array}$ & \multirow[t]{2}{*}{-} \\
\hline & $\begin{array}{l}\text { HBIG + vaccine, 0, 1, } 6 \text { mo, } \\
\text { HBsAg }^{+}, 9.26 \% \text { (Chen et al. } \\
\text { 2012) }\end{array}$ & $\begin{array}{l}\text { Vaccine, } 0,1,6 \mathrm{mo} \\
\mathrm{HBsAg}^{+}, 0.29 \%\end{array}$ & \\
\hline
\end{tabular}

${ }^{\mathrm{a}} \mathrm{HBsAg}^{+}$rate in high-risk infants (in comparison to controls with no vaccine or HBIG).

had passive antibodies, indicating that the preexisting anti-HBs did not interfere with the immunogenicity of the vaccine (Lee et al. 1983) (Table 2).

Since the HBV vaccine became available in 1982, more than one billion doses of the vaccine have been used worldwide. Active immunization with three or four doses of HBV vaccine without $\mathrm{HBIG}$ was proved to be immunogenic in more than $90 \%$ of infants of noncarrier mothers or HBeAg-negative carrier mothers. In infants of highly infectious (HBeAg seropositive
HBsAg carrier) mothers, the prevention efficacy of using HBV vaccines was only $\sim 75 \%$ (Table 2 ) (Beasley et al. 1983c).

\section{Combination of Passive and Active Immunization}

A pilot clinical trial combining active and passive immunization with injection of $\mathrm{HBIG}$ within $24 \mathrm{~h}$ after birth followed by three doses of $\mathrm{HBV}$ vaccine further reduced the HBsAg carrier rate to $3 \%$ in infants. The results of early 
Prevention of Hepatitis B

clinical trials for HBV immunization conducted in Taiwan established the ground for the universal HBV immunization strategies and programs used currently.

In the first randomized blind controlled trial combining HBIG plus the HBV vaccine, infants of HBeAg-positive, HBsAg carrier mothers were given HBIG immediately after birth, followed by one of the three schedules of HBV vaccination. No difference in efficacy between the three schedules was noted; the combined prevention efficacy was $94 \%$ versus HBIG alone $(71 \%)$ or vaccine alone $(75 \%)$. Persistent HBs antigenemia developed in only $6 \%$ of infants receiving prophylaxis, but in $88 \%$ of the controls (without prophylaxis). Anti-HBs developed in all those who did not become antigenemic (Beasley et al. 1983c). The best result of HBV prevention against perinatal transmission of HBV infection by highly infectious mothers was thus established to be the combination of HBIG with the hepatitis B vaccine. This study recommended that HBIG should be given as soon as possible after birth and need not be given again if the infant is subsequently vaccinated. A similar study was performed also in Taiwan with another plasma-derived vaccine with a slightly different schedule (Lo et al. 1985). The result also showed that combining HBIG with a hepatitis $B$ vaccine had the highest efficacy reaching $90 \%$ versus $74 \%$ in those who received only the vaccine. These studies provided the basis for the subsequent HBV universal immunization programs.

\section{Prevention Efficacy of Recombinant HBV Vaccine with HBIG}

Among infants who received HBIG at birth and three 5- $\mu$ g doses of yeast-recombinant hepatitis B vaccine, only $4.8 \%$ became chronic carriers, a greater than $90 \%$ level of protection and a rate comparable with that seen with HBIG and plasma-derived hepatitis B vaccine. These results suggested that, in this high-risk setting, the yeast-recombinant vaccine was at least as effective as the plasma-derived vaccine in preventing HBV infection and the chronic carrier state (Stevens et al. 1987).

\section{THE EARLIEST UNIVERSAL HBV MASS IMMUNIZATION PROGRAM}

The first universal hepatitis B mass vaccination program in the world was launched in Taiwan in July 1984. Pregnant women were screened for $\mathrm{HBsAg}$ and then HBeAg. Infants of mothers negative for $\mathrm{HBeAg}$ or $\mathrm{HBsAg}$ received the plasma-derived hepatitis $B$ vaccine only at $0,1,2$, and 12 mo. The vaccine was shifted to a recombinant hepatitis B vaccine at 0,1 , and 6 mo after October 1992. The immunization program in the initial 2 years (July 1984 to June 1986) covered only infants of HBsAg carrier mothers. From the third year on, all of the infants were covered. Infants of highly infectious mothers with positive $\mathrm{HBeAg}$ received $\mathrm{HBIG}$ within $24 \mathrm{~h}$ after birth in addition to the hepatitis B vaccine. The coverage rate of hepatitis $B$ vaccine for neonates was $\sim 94 \%$ in initial years, and was $\sim 99 \%$ recently. Catch-up vaccination was also given to preschool and then school children (Chen et al. 1987).

The efficacy of the Taiwanese mass hepatitis $B$ immunization program was evaluated in 3464 18-mo-old vaccinated infants of HBsAg carrier mothers. In 786 infants born to highly infectious mothers who had received HBIG and vaccine on schedule, the protective efficacy was $\sim 85 \%$. Overall, $11 \%$ of infants still carried HBsAg, and $81 \%$ had anti-HBs (>10 mIU/ $\mathrm{mL}$ in more than $90 \%$ ) (Table 2). The geometric mean titers of anti-HBs were $>200 \mathrm{mIU} / \mathrm{mL}$ in every group of infants. According to a random sampling study of children in Taiwan 3 years after implementing the universal $\mathrm{HBV}$ vaccination program, the protective efficacy was $86 \%$ in the HBIG plus HBV vaccine group and was $78 \%$ in those with three doses of HBV vaccine alone (Hsu et al. 1988).

\section{GLOBAL VIEW OF HBV IMMUNIZATION}

In 2009, the World Health Organization (WHO) recommended that all infants receive the hepatitis B vaccine as soon as possible after birth, preferably within $24 \mathrm{~h}$. The birth dose should be followed by two or three doses to complete 
the primary series. In 1992, the World Health Assembly passed a resolution to recommend global vaccination against hepatitis B. Furthermore, as of July 2011, 93 member states have introduced the hepatitis B birth dose (www .who.int/mediacentre/factsheets/fs204/en). WHO recommended that high-risk groups should be vaccinated. They include (1) people who frequently require blood and/or blood products, dialysis patients, recipients of solid organ transplantations; (2) people interned in prisons; (3) IV drug users; (4) household and sexual contacts of people with chronic HBV infection; (5) people with multiple sexual partners, health-care workers, and others who are exposed to blood or blood products through work; and (6) travelers who have not completed their hepatitis $B$ vaccination series before leaving for endemic areas.

The global hepatitis B vaccine coverage rate was estimated at $75 \%$, and was as high as $91 \%$ in the Western Pacific and $89 \%$ in the Americas. Coverage in Southeast Asia reached 52\% in 2010. In 2011, 180 countries had introduced infant $\mathrm{HBV}$ vaccination, and the global $\mathrm{HBV}$ vaccination coverage rate for the third dose was estimated to be $\sim 78 \%$.

Universal HBV vaccination in infancy is more effective than selective immunization for high-risk groups. Slightly different immunization strategies or schedules are used in different countries, depending on epidemiologic features of HBV infection and available resources (Chen 2009). In many endemic countries with limited resources, three doses of hepatitis $B$ vaccine are given to all infants, regardless of the maternal HBsAg status. This strategy offers an efficacy of $\sim 75 \%$ to $80 \%$ for infants of highly infectious HBeAg-positive mothers. Nevertheless, the cost of maternal screening and subsequent use of HBIG in the newborns can be avoided. In countries with low prevalence of HBV infection and better resources, HBIG is given to newborns of all HBsAg-positive mothers regardless of their HBeAg status, and all infants received three doses of the HBV vaccine. Although the cost of maternal screening for $\mathrm{HBeAg}$ can be saved, the wider use of HBIG increases the cost substantially.

\section{PREVENTION OF DISEASES BY HBV VACCINATION}

Hepatitis B vaccine provides protection against HBV infection and its complications, including fulminant hepatitis, chronic hepatitis, liver cirrhosis, and HCC, as well as membranous nephropathy. It is the first vaccine against a cancer, the first vaccine protecting from a sexually transmitted infection, and the first vaccine against a chronic disease (Lavanchy 2012).

Prevention of HBV Infection, Hepatitis B, and Nephropathy

After universal HBV immunization, the incidence of acute hepatitis B declined (Wasley et al. 2007; McMahon et al. 2011; Su et al. 2012). Owing to breakthrough HBV infection from mother-to-infant transmission, vaccinated infants had higher rates of infection $(0.78 /$ $100,000)$ than those aged 1-14 yr (0.04/ $100,000)$, who had the lowest rates. After 25 years of universal HBV immunization in Taiwan, acute hepatitis B among adolescents and young adults $\leq 25 \mathrm{yr}$ old was markedly reduced, rendering the previously unvaccinated 25 - to 39 yr-old cohort additional targets for the prevention of acute hepatitis B (Kao and Chen 2008).

The mortality associated with fulminant hepatitis in infants has also declined significantly (Kao et al. 2001; Chiang et al. 2013). In addition, HBVMN in the vaccinated children also decreased drastically, very likely because of the reduction in horizontal transmission of $\mathrm{HBV}$ infection after universal $\mathrm{HBV}$ vaccination (Liao et al. 2011).

An $\sim 90 \%$ reduction of chronic HBV infection rate has been achieved after the HBV immunization program. We conducted serial seroepidemiologic surveys of HBV markers before and $5,10,15$, and 20 years after the implementation of the vaccination program in Taipei, Taiwan (Hsu et al 1986; Chen et al. 1996; Ni et al. 2001, 2007, 2012). The HBsAg carrier rate decreased steadily from $\sim 10 \%$ before the vaccination program to $0.6 \%-0.7 \%$ afterward in vaccinated children younger than $20 \mathrm{yr}$ of age. The infection rate (anti-HBc seropositive rate) 
declined from $38 \%$ to $16 \%$ and further to $4.6 \%$ in children $15-20$ years after the program $(\mathrm{Ni}$ et al. 2007).

Similar effects have also been observed in many other countries where universal vaccination programs have been successfully conducted. The HBsAg seropositive rates declined to below $1 \%$ in most countries after hepatitis B immunization (Chen 2009). In Gambia, all nonimmune children under the age of $5 \mathrm{yr}$ in the villages of Keneba and Manduar were vaccinated against $\mathrm{HBV}$ in 1984. Overall, vaccine efficacies in 1993 against $\mathrm{HBV}$ infection and chronic HBsAg carriage were $94.7 \%$ and $95.3 \%$, respectively (Whittle et al. 1995). In 2007-2008, a seroepidemiologic study in Gambia showed the effectiveness of the hepatitis B vaccination that was implemented in 1986. Comparing fully vaccinated versus unvaccinated Gambians, HBV infection was $0.8 \%(2 / 255)$ versus $12.4 \%$ (59/475), indicating an efficacy of $94 \%$. For $\mathrm{HBV}$ infection, the anti-HBc positivity rate was $27.4 \%(70 / 255)$ and 56.0\% (267/475), respectively. The protection yielded by HBV vaccination persisted beyond the onset of sexual activities, suggesting that there was no need for a booster dose (Peto et al. 2014).

\section{Prevention of HCC}

Taiwan has a high prevalence of HBV infection and HCC both in children and adults. Children with HCC in Taiwan are nearly 100\% HBsAg seropositive, $86 \%$ of them are $\mathrm{HBeAg}$ negative, and their mothers are mostly (94\%) HBsAg seropositive, suggesting maternal transmission as the source of HBV infection (Chang et al. 1989).

Prevention of chronic HBV infection by immunization can reduce the incidence of liver cancer. As shown in our previous studies, the incidence of HCC among children 6-19 yr old born after the universal HBV vaccination program was reduced to $\sim 30 \%-32 \%$ of that among those born before the program was in effect in Taiwan (Chang et al. 1997, 2009).

Studies elsewhere also showed declines in the HCC incidence in children as a result of infant HBV immunization in Khon Kaen, Thailand, and Alaska, United States. The incidence of HCC is significantly lower in Thai children who receive the hepatitis $\mathrm{B}$ vaccine at birth. The age-standardized incidence rates for liver cancer in Thai children over $10 \mathrm{yr}$ of age of nonvaccinated and vaccinated children were 0.88 and 0.07 per million, respectively (Wichajarn et al. 2008). After 25 years of universal newborn vaccination coupled with mass screening and immunization of susceptible Alaska Natives, HCC was eliminated among Alaska Native children. The incidence of HCC in adolescence below the age of 20 decreased from three per 100,000 in $1984-1988$ to zero in 1995-1999, and no cases have occurred since 1999 (McMahon et al. 2011).

\section{PROBLEMS TO BE SOLVED FOR A BETTER CONTROL OF HEPATITIS B AND ITS SEQUELAE}

\section{Inadequate Resources}

Universal HBV immunization programs still have not been established all over the world, mainly because of limited resources. In some areas, universal HBV vaccination has been implemented, yet the cost of vaccination is not covered by the government. Further increase of the global coverage rates of infant $\mathrm{HBV}$ vaccination is an important issue toward a better control of hepatitis B and HCC. Coverage of the expenses of HBV vaccination in developing countries by the government or establishing a vaccine fund is important to expand the HBV vaccine coverage. It is particularly urgent in areas where HBV infection and HCC are endemic (Lerkhachonsuk et al. 2013).

\section{Poor Compliance}

In areas with adequate resources and an established program of universal HBV immunization, poor compliance may still be a problem. The number of people with ignorance or opposition to the HBV vaccines may be reduced after a better understanding of the extremely low incidence of vaccine-related side effects. For instance, although there is little supporting evidence, an association between CNS demyelin- 
ating diseases and hepatitis $\mathrm{B}$ vaccine has been implied repeatedly (Chen 2009). On the basis of critical systematic review of current data, no significant increased risk in onset or relapse of any diseases was associated with hepatitis B vaccination (Martínez-Sernández and Figueiras 2013). Clarification of some other poorly documented side effects of the vaccines may help to reduce anxiety about the risks of the vaccine and, as a consequence, enhance HBV vaccine coverage rate. Furthermore, in some developed countries, because of the competition from other new vaccines, HBV has not captured sufficient attention from the government (Van Herck et al. 2008).

\section{Vaccine Failure}

The causes of breakthrough HBV infection in the vaccinated subjects include high maternal viral load, intrauterine infection (Lin et al. 1987; Tang et al. 1998), surface-gene mutants (Hsu et al. 2010), genetic hyporesponsiveness to the vaccine (Kruskall et al. 1992), and immune compromised hosts. In the era of postHBV vaccination, even after complete immunization, vaccine failure still occurs. The leading cause of vaccine failure is the mother-to-infant transmission of HBV from highly infectious mothers (Chen et al. 2012). In children born to $\mathrm{HBeAg}$-seropositive HBsAg carrier mothers, despite HBIG and three doses of the HBV vaccine, 9.26\% still became HBsAg positive. In contrast, in children born to $\mathrm{HBeAg-negative,}$ HBsAg-seropositive mothers, only $0.29 \%$ became HBsAg positive if no HBIG was given at birth, and $0.14 \%$ became $\mathrm{HBsAg}$ positive if HBIG was given at birth $(P=0.65)$. The predictive infection rates of vaccinated infants at maternal viral load levels of 7,8 , and $9 \log 10$ copies $/ \mathrm{mL}$ were $6.6 \%, 14.6 \%$, and $27.7 \%$, respectively (Wen et al. 2013).

Vaccine failure has been attributed to hepatitis B surface-gene mutants. Compared with the unvaccinated subjects $(7.8 \%)$, the prevalence rate of the hepatitis B surface gene $a$ mutant increased to $22 \%-28 \%$ among vaccinated HBsAg carriers. However, the prevalence rate of the mutants among the total population has remained stationary for 20 years because HBV vaccination reduced the HBsAg seropositive rates in the vaccinated population. Less infectivity of G145R, recombinant vaccine use, and mutant loss with older age seem to decrease the $a$ mutant prevalence in an immunized population over time (Hsu et al. 2010, 2013).

Infants of HBsAg carrier mothers with positive $\mathrm{HBeAg}$ and high viral load are the highrisk group of breakthrough $\mathrm{HBV}$ infection, despite immune prophylaxis with a combination of passive (HBIG) and active (vaccine) immunization. Continuing efforts are needed to prevent breakthrough infection of $\mathrm{HBV}$ by highly infectious mothers. Preliminary results using anti-HBV nucleoside analog during the last trimester of pregnancy to prevent mother-to-infant transmission have been reported (van Zonneveld et al. 2003; Xu et al. 2009; Han et al. 2011). However, further studies are needed to determine the efficacy versus adverse responses and cost effectiveness in reducing mother-to-infant transmission from highly viremic mothers.

\section{Duration of Protection after HBV Immunization in Infancy}

Anti-HBs titers gradually decline with age in children immunized in infancy with hepatitis $B$ vaccine, which is also seen in those who received a booster dose during childhood (Wang et al. 2005). In a prospective long-term followup study of $1200 \mathrm{HBV}$ vaccinees in the general population (from 7 to 16 yrold), the annual new anti-HBc seropositive rate was low $(0.13 \%)$, and no new chronic HBV infection was detected. The decay rate of anti-HBs titer during age 716 yr was $\sim 20 \%$ of the titer of the previous year. Among the uninfected children who had anti-HBs $<10 \mathrm{mIU} / \mathrm{mL}$, the boosted and nonboosted children developed new anti-HBc positivity at a similar rate, indicating that a vaccine booster at this age is not necessary (Lin et al. 2003).

How long can the protection by HBV vaccination last? The proportions of postbooster anti-HBs titer $<10 \mathrm{mIU} / \mathrm{mL}$ among $15-23 \mathrm{yr}$ olds was $24 \%-28 \%$ (Jan et al. 2010). In another 
Prevention of Hepatitis B

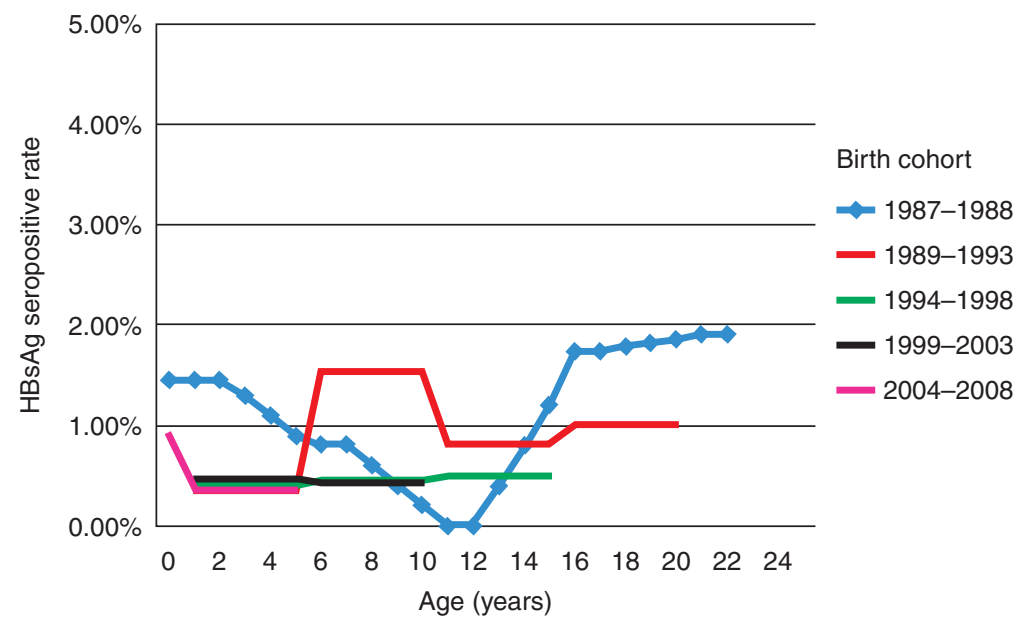

Figure 1. Long-term serial seropidemiologic surveys showing no increase of HBsAg-positive rates for at least 20 years in Taiwan (Ni et al. 2012).

study, a booster dose of HBV vaccination was administered to $1974 \mathrm{HBsAg-}$ and anti-HBsnegative subjects. The proportions of postbooster anti-HBs titer $<10 \mathrm{mIU} / \mathrm{mL}$ was 27.9\% (Wu et al. 2013). Even if studies show a loss of immune memory by this method, this does not necessarily mean that booster doses are required (Hall 2010). Loss of antibody among those who received HBV vaccination during infancy may not indicate loss of immunity or protection. Evidence on several critical end points, such as protection against infection and rates of anti-HBc conversion in vaccinated populations by age, and protection against diseases are more important than the anti-HBs titers (Chen 2005). There had been no increase of HBsAg seropositive rates in cohorts born after the HBV vaccination program was set into place as found in the five consecutive surveys in Taiwan (Fig. 1) (Ni et al. 2012). For those who had received vaccinations in infancy, routine booster vaccination may not be required to protect against chronic $\mathrm{HBV}$ infection at least before $25 \mathrm{yr}$ of age. The WHO also suggested that routine universal boosters are not recommended for children or adolescents. Nevertheless, it should be considered for those at high risk of HBV infection with anti-HBs $<10 \mathrm{mIU} /$ $\mathrm{mL}$ after primary $\mathrm{HBV}$ vaccination (www.who .int/mediacentre/factsheets/fs204/en).

\section{CONCLUDING REMARKS}

Prevention is critical in the control of HBV infection. This is particularly important in places where HBV infection, chronic liver disease, and HCC are prevalent. The hepatitis B vaccine is the first vaccine against a major human cancer. To achieve better results in HBV prevention worldwide, higher coverage rates of $\mathrm{HBV}$ vaccination, better strategies against breakthrough infection and for nonresponders, and good long-term protection are needed. It is of vital importance to convince the governments of countries without a universal HBV vaccination program to establish and implement such a program, and to help the countries with insufficient coverage rates to improve their vaccination programs. With the universal hepatitis B vaccination program starting from neonates in most countries, HBV infection and its sequelae will be further reduced, or even eradicated (Chen 2009). The concept of a cancer preventive vaccine, using $\mathrm{HBV}$ as an example, can be extended further to other infectious agents and their related cancers.

\section{ACKNOWLEDGMENTS}

We appreciate Professor R. Palmer Beasley, Dr. Lu-Yu Hwang, and Mrs. R. P Beasley for allowing us to use the unpublished data from their study. 
M.-H. Chang and D.-S. Chen

\section{REFERENCES}

Beasley RP. 2009. Rocks along the road to the control of HBV and HCC. Ann Epidemiol 19: 231-234.

Beasley RP, Hwang LY, Lin CC, Leu ML, Stevens CE, Szmuness W, Chen KP. 1982. Incidence of hepatitis B virus infections in preschool children in Taiwan. J Infect Dis 146: $198-204$.

Beasley RP, Hwang LY, Lin CC, Ko YC, Twu SJ. 1983a. Incidence of hepatitis among students at a university in Taiwan. Am J Epidemiol 117: 213-222.

Beasley RP, Hwang LY, Stevens CE, Lin CC, Hsieh FJ, Wang KY, Sun TS, Szmuness W. 1983b. Efficacy of hepatitis B immune globulin for prevention of perinatal transmission of the hepatitis B virus carrier state: Final report of a randomized double-blind, placebo-controlled trial. Нерatology 3: 135-141.

Beasley RP, Hwang LY, Lee GC, Lan CC, Roan CH, Huang FY, Chen CL. 1983c. Prevention of perinatally transmitted hepatitis $B$ virus infections with hepatitis B immune globulin and hepatitis B vaccine. Lancet 2: 1099-1102.

Blumberg BS, Gerstley BJ, Hungerford DA, London WT, Sutnick AI. 1967. A serum antigen (Australia antigen) in Down's syndrome, leukemia, and hepatitis. Ann Intern Med 66: 924-931.

Blumberg BS, Sutnick AI, London WT.1969. Australia antigen and hepatitis. JAMA 207: 1895-1896.

Buynak EB, Roehm RR, Tytell AA, Bertland AU II, Lampson GP, Hilleman MR.1976. Vaccine against human hepatitis B. JAMA 235: 2832-2834.

Chang MH, Lee CY, Chen DS, Hsu HC, Lai MY. 1987. Fulminant hepatitis in children in Taiwan: The important role of hepatitis B virus. J Pediatr 111: 34-39.

Chang MH, Chen DS, Hsu HC, Hsu HY, Lee CY.1989. Maternal transmission of hepatitis B virus in childhood HCC. Cancer 64: 2377-2380.

Chang MH, Chen CJ, Lai MS, Hsu HM, Wu TC, Kong MS, Liang DC, Shau WY, Chen DS, Taiwan Childhood Hepatoma Study Group. 1997. Universal hepatitis B vaccination in Taiwan and the incidence of hepatocellular carcinoma in children. $N$ Engl J Med 336: 1855-1859.

Chang MH, You SL, Chen CJ, Liu CJ, Lee CM, Lin SM, Chu HC, Wu TC, Yang SS, Kuo HS, et al. 2009. Decreased incidence of hepatocellular carcinoma in hepatitis B vaccinees: A 20-year follow-up study. J Natl Cancer Inst 101: $1348-1355$.

Chen DS. 2005. Ling-term protection of hepatitis B vaccine: Lessons from Alaskan experience after 15 years. Ann Intern Med 142: 384-385.

Chen DS. 2009. Hepatitis B vaccination: The key towards elimination and eradication of hepatitis B. J Hepatol 50: 805-816.

Chen DS. 2011. Fighting against hepatitis B: Lessons from Taiwan. Hepatology 54: 381-392.

Chen DS, Hsu NHM, Sung JL, Hsu TC, Hsu ST, Kuo YT, Lo KJ, Shih YT. 1987. The Hepatitis Steering Committee, The Hepatitis Control Committee: A mass vaccination program in Taiwan against hepatitis B virus infection in infants of hepatitis $B$ surface antigen carrier-mothers. JAMA 257: 2597-2603.
Chen HL, Chang MH, Ni YH, Hsu HY, Lee PI, Lee CY, Chen DS. 1996. Seroepidemiology of hepatitis B virus infection in children: Ten years of mass vaccination in Taiwan. JAMA 276: 906-908.

Chen HL, Lin LH, Hu FC, Lee JT, Lin WT, Yang YJ, Huang FC, Wu SF, Chen SC, Wen WH, et al. 2012. Effects of maternal screening and universal immunization to prevent mother-to-infant transmission of HBV. Gastroenterology 142: 773-781.

Chiang CJ, Yang YW, You SL, Lai MS, Chen CJ. 2013. Thirtyyear outcomes of the National Hepatitis B Immunization Program in Taiwan. JAMA 310: 974-976.

Hall AJ. 2010. Boosters for hepatitis B vaccination? Need for an evidence-based policy. Hepatology 51: 1485-1486.

Han GR, Cao MK, Zhao W, Jiang HX, Wang CM, Bai SF, Yue X, Wang GJ, Tang X, Fang ZX. 2011. A prospective and open-label study for the efficacy and safety of telbivudine in pregnancy for the prevention of perinatal transmission of hepatitis B virus infection. J Hepatol 55: 1215-1221.

Hilleman MR. 1987. Yeast recombinant hepatitis B vaccine. Infection 15: 3-7.

Hsu HC, Lin GH, Chang MH, Chen HC. 1983. Association of hepatitis B surface antigenemia and membranous nephropathy in children in Taiwan. Clin Nephrol 20: 121129.

Hsu HY, Chang MH, Chen DS, Lee CY, Sung JL. 1986. Baseline seroepidemiology of hepatitis B virus infection in children in Taipei, 1984: A study just before mass hepatitis B vaccination program in Taiwan. J Med Virol 18: 301-307.

Hsu HM, Chen DS, Chuang CH, Lu JC, Jwo DM, Lee CC, Lu HC, Cheng SH, Wang YF, Wang CY. 1988. Efficacy of a mass hepatitis B vaccination program in Taiwan: Studies on 3464 infants of hepatitis B surface antigen-carrier mothers. JAMA 260: 2231-2235.

Hsu HY, Chang MH, Ni YH, Chiang CL, Chen HL,Wu JF, Chen PJ. 2010. No increase in prevalence of hepatitis B surface antigen mutant in a population of children and adolescents who were fully covered by universal infant immunization. J Infect Dis 201: 1192-1200.

Hsu HY, Chang MH, Ni YH, Jeng YM, Chiang CL, Chen HL, Wu JF, Chen PJ. 2013. Long-term follow-up of children with postnatal immunoprophylaxis failure who were infected with hepatitis B virus surface antigen gene mutant. J Infect Dis 207: 1047-1057.

Jan CF, Huang KC, Chien YC, Greydanus DE, Davies HD, Chiu TY, Huang LM, Chen CJ, Chen DS. 2010. Determination of immune memory to hepatitis $\mathrm{B}$ vaccination through early booster response in college students. Hepatology 51: 1547-1554.

Kao JH, Chen DS. 2008. Universal hepatitis B vaccination: Killing 2 birds with 1 stone. Am J Med 121: 1029-1031.

Kao JH, Hsu HM, Shau WY, Chang MH, Chen DS. 2001. Universal hepatitis B vaccination and the decreased mortality from fulminant hepatitis in infants in Taiwan. $J$ Pediatr 139: 349-352.

Kappus MR, Sterling RK. 2013. Extrahepatic manifestations of acute hepatitis B virus infection. Gastroenterol Hepatol 9: $123-126$. 
Kruskall MS, Alper CA, Awdeh Z, Yunis EJ, Marcus-Bagley D. 1992. The immune response to hepatitis B vaccine in humans: Inheritance patterns in families. J Exp Med; 175: 495-502.

Lavanchy D. 2012. Viral hepatitis: Global goals for vaccination. J Clin Virol 55: 296-302.

Lee GC, Hwang LY, Beasley RP, Chen SH, Lee TY. 1983. Immunogenicity of hepatitis B virus vaccine in healthy Chinese neonates. J Infect Dis 148: 526-529.

Lee CY, Huang LM, Chang MH, Hsu CY, Wu SJ, Sung JL, Safary A.1991. The protective efficacy of recombinant hepatitis $B$ vaccine in newborn infants of hepatitis B e antigen-positive-hepatitis B surface antigen carrier mothers. Pediatr Infect Dis J 10: 299-303.

Lerkhachonsuk AA, Yip CH, Khuhaprema T, Chen DS, Piummer M, Jee SH, Toi M, Willailak S, Asian Oncology Summit. 2013. Cancer prevention in Asia: Resourcestratified guidelines from the Asian Oncology Summit 2013. Lancet Oncol 14: 497-507.

Liao MT, Chang MH, Lin FG, Tsai IJ, Chang YW, Tsau YK. 2011. Universal hepatitis B vaccination reduces childhood hepatitis B virus-associated membranous nephropathy. Pediatrics 128: e600-e604.

Lin HH, Lee TY, Chen DS, Sung JL, Ohto H, Etoh T, Kawana T, Mizuno M. 1987. Transplacental leakage of HBeAgpositive maternal blood as the most likely route in causing intrauterine infection with hepatitis B virus. J Pediatr 111: $877-881$.

Lin YC, Chang MH, Ni YH, Hsu HY, Chen DS. 2003. Long-term immunogenicity and efficacy of universal hepatitis B virus vaccination in Taiwan. J Infect Dis 187: 134-138.

Lo KJ, Tsai YT, Lee SD, Yeh CL, Wang JY, Chiang BN, Wu TC, Yeh PS, Goudeau A, Coursaget P. 1985. Combined passive and active immunization for interruption of perinatal transmission of hepatitis B virus in Taiwan. Hepatogastroenterology 32: 65-68.

Martínez-Sernández V, Figueiras A. 2013. Central nervous system demyelinating diseases and recombinant hepatitis B vaccination: A critical systematic review of scientific production. J Neurol 260: 1951-1959.

Maupas P, Chiron JP, Barin F, Coursaget P, Goudeau A, Perrin J, Denis F, Mair ID. 1981. Efficacy of hepatitis B vaccine in prevention of early $\mathrm{HBsAg}$ carrier state in children. Controlled trial in an endemic area (Senegal). Lancet i: $289-292$.

McMahon BJ, Bulkow LR, Singleton RJ, Williams J, Snowball M, Homan C, Parkinson AJ. 2011. Elimination of hepatocellular carcinoma and acute hepatitis B in children 25 years after a hepatitis B newborn and catch-up immunization program. Hepatology 54: 801-807.

Ni YH, Chang MH, Huang LM, Chen HL, Hsu HY, Chiu TY, Tsai KS, Chen DS. 2001. Hepatitis B virus infection in children and adolescents in a hyperendemic area: 15 years after mass hepatitis B vaccination. Ann Intern Med 135: 796-800.

Ni YH, Huang LM, Chang MH, Yen CJ, Lu CY, You SL, Kao JH, Lin YC, Chen HL, Hsu HY, et al. 2007. Two decades of universal hepatitis B vaccination in Taiwan: Impact and implication for future strategies. Gastroenterology 132: 1287-1293.
Ni YH, Chang MH, Wu JF, Hsu HY, Chen HL, Chen DS. 2012. Minimization of hepatitis B infection by a 25-year universal vaccination program. $J$ Hepatol 57: $730-735$.

Peto TJ, Mendy ME, Lowe Y, Webb EL, Whittle HC, Hall AJ. 2014. Efficacy and effectiveness of infant vaccination against chronic hepatitis B in the Gambia Hepatitis Intervention Study (1986-90) and in the nationwide immunisation program. BMC Infect Dis 14: 7.

Shiraki K, Yoshihara N, Sakurai M, Eto T, Kawana T. 1980. Acute hepatitis B in infants born to carrier mother with the antibody to hepatitis B e antigen. J Pediatr 97: 768770 .

Stevens CE, Beasley RP, Tsui J, Lee WC. 1975. Vertical transmission of hepatitis B antigen in Taiwan. N Engl J Med 292: 771-774.

Stevens CE, Taylor PE, Tong MJ, Toy PT, Vyas GN, Nair PV, Weissman JY, Krugman S. 1987. Yeast-recombinant hepatitis B vaccine. Efficacy with hepatitis B immune globulin in prevention of perinatal hepatitis B virus transmission. JAMA 257: 2612-2616.

Su WJ, Liu CC, Liu DP, Chen SF, Huang JJ, Chan TC, Chang MH. 2012. Effect of age on the incidence of acute hepatitis B after 25 years of a universal newborn hepatitis B immunization program in Taiwan. J Infect Dis 205: 757-62.

Szmuness W, Stevens CE, Harley EJ, Zang EA, Oleszko WR, William DC, Sadovsky R, Morrison JM, Kellner A. 1980. Hepatitis B vaccine: Demonstration of efficacy in a controlled clinical trial in a high-risk population in the United States. N Engl J Med 303: 833-841.

Tang JR, Hsu HY, Lin HH, Ni YH, Chang MH.1998. Hepatitis B surface antigenemia at birth: A long-term followup study. J Pediatr 133: 374-377.

Tsai YT, Lo KJ, Lee SD, Wang JY, Wu TC. 1984. Immunoprophylaxis against hepatitis B virus infection: A controlled trial in infants born to $\mathrm{HBeAg}$-negative $\mathrm{HBsAg}$ carrier mothers in Taiwan. Chinese J Gastroenterol 1: 181-185.

Valenzuela P, Medina A, Rutter WJ, Ammerer G, Hall BD. 1982. Synthesis and assembly of hepatitis B virus surface antigen particles in yeast. Nature 298: 347-350.

van Herck K, Vorsters A, Van Damme P. 2008. Prevention of viral hepatitis (B and C) reassessed. Best Pract Res Clin Gastroenterol 22: 1009-1029.

van Zonneveld $M$, van Nunen AB, Niesters HG, de Man RA, Schalm SW, Janssen HL. 2003. Lamivudine treatment during pregnancy to prevent perinatal transmission of hepatitis B virus infection. J Viral Hepat 10: 294-297.

Wang CW, Wang LC, Chang MH, Ni YH, Chen HL, Hsu HY, Chen DS. 2005. Long-term follow-up of hepatitis B surface antibody levels in subjects receiving universal hepatitis B vaccination in infancy in an area of hyperendemicity: Correlation between radioimmunoassay and enzyme immunoassay. Clin Diagn Lab Immunol 12: $1442-1447$.

Wasley A, Miller JT, Finelli L, Centers for Disease Control and Prevention (CDC). 2007. Surveillance for acute viral hepatitis-United States, 2005. MMWR Surveill Summary 56: 1-24. 
M.-H. Chang and D.-S. Chen

Wen WH, Chang MH, Zhao LL, Ni YH, Hsu HY, Wu JF, Chen PJ, Chen DS, Chen HL. 2013. Mother-to-infant transmission of hepatitis B virus infection: Significance of maternal viral load and strategies for intervention. $J$ Hepatol 59: 24-30.

Whittle HC, Maine N, Pilkington J, Mendy M, Fortuin M, Bunn J, Allison L, Howard C, Hall A.1995. Long-term efficacy of continuing hepatitis B vaccination in infancy in two Gambian villages. Lancet 345: 1089-92.

Wichajarn K, Kosalaraksa P, Wiangnon S. 2008. Incidence of HCC in children in Khon Kaen before and after national hepatitis B vaccine program. Asian Pac J Cancer Prev 9: 507-509.
Wu TW, Lin HH, Wang LY. 2013. Chronic hepatitis B infection in adolescents who received primary infantile vaccination. Hepatology 57: 37-45.

Xu WM, Cui YT, Wang L, Yang H, Liang ZQ, Li XM, Zhang SL, Qiao FY, Campbell F, Chang CN, et al. 2009. Lamivudine in late pregnancy to prevent perinatal transmission of hepatitis B virus infection: A multicentre, randomized, double-blind, placebo-controlled study. $J$ Viral Hepat 16: 94-103.

Yang JJ, Liu CC, Chen TJ, Lee MF, Chen SH, Shih HH, Chang MH. 2003. Role of hepatitis B immunoglobulin in infants born to hepatitis B e antigen-negative carrier mothers in Taiwan. Pediatr Infect Dis J 22: 584-588. 


\title{
$\&_{\mathrm{CSH}}^{\infty} \&$ Cold Spring Harbor

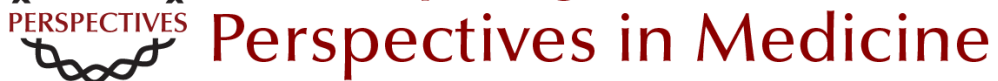

\section{Prevention of Hepatitis B}

\author{
Mei-Hwei Chang and Ding-Shinn Chen \\ Cold Spring Harb Perspect Med 2015; doi: 10.1101/cshperspect.a021493
}

Subject Collection The Hepatitis B and Delta Viruses

\section{Hepatitis B Virus X and Regulation of Viral Gene Expression \\ Betty L. Slagle and Michael J. Bouchard}

The Woodchuck, a Nonprimate Model for Immunopathogenesis and Therapeutic Immunomodulation in Chronic Hepatitis B Virus Infection

Michael Roggendorf, Anna D. Kosinska, Jia Liu, et al.

Mouse Models of Hepatitis B Virus Pathogenesis Matteo lannacone and Luca G. Guidotti

Therapy of Delta Hepatitis

Cihan Yurdaydin and Ramazan Idilman

Immune Response in Hepatitis B Virus Infection Anthony Tan, Sarene Koh and Antonio Bertoletti

Hepatitis D Virus: Introduction and Epidemiology Mario Rizzetto

Management of Chronic Hepatitis B in Patients from Special Populations

Ching-Lung Lai and Man-Fung Yuen

Hepatitis B Virus Genotypes and Variants

Chih-Lin Lin and Jia-Horng Kao
Origins and Evolution of Hepatitis B Virus and Hepatitis D Virus

Margaret Littlejohn, Stephen Locarnini and Lilly Yuen

Assembly and Release of Hepatitis B Virus Lisa Selzer and Adam Zlotnick

Hepatitis D Virus Replication John M. Taylor

Treatment of Liver Cancer

Chun-Yu Liu, Kuen-Feng Chen and Pei-Jer Chen

Hepatitis B Virus and Hepatitis D Virus Entry, Species Specificity, and Tissue Tropism Koichi Watashi and Takaji Wakita

Hepadnavirus Genome Replication and

Persistence Jianming Hu and Christoph Seeger

The Chimpanzee Model for Hepatitis B Virus Infection Stefan F. Wieland

Hepatitis B Virus Epidemiology Jennifer H. MacLachlan and Benjamin C. Cowie

For additional articles in this collection, see http://perspectivesinmedicine.cshlp.org/cgi/collection/ 